\title{
Racial Prejudice and Police Stops: A Systematic Review of the Empirical Literature
}

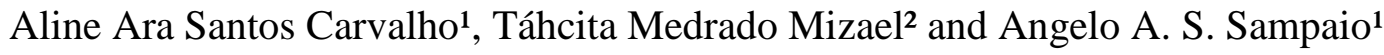

${ }^{1}$ Department of Psychology, Federal University of Vale do São Francisco (Univasf), Brazil

${ }^{2}$ Department of Experimental Psychology, University of São Paulo (USP), Brazil

\section{Author's ORCIDs:}

Aline Carvalho: https://orcid.org/0000-0002-6436-2663

Táhcita Mizael: https://orcid.org/0000-0002-5543-1188

Angelo Sampaio: https://orcid.org/0000-0001-7154-0862

\section{Author Note}

The present research was based on the undergraduate thesis in Psychology of the first author, under the supervision of the third author and the co-supervision of the second author. Táhcita Mizael was supported by a Post-Doctoral fellowship from the São Paulo Research Foundation (Grant \# 2020/02548-7) and also by the scientific program of Instituto Nacional de Ciência e Tecnologia sobre Comportamento, Cognição e Ensino (INCT-ECCE), supported by CNPq (Grants 573972/2008-7 and 465686/2014-1) and FAPESP (Grants 2008/57705- 8 and 2014/50909-8). The authors would like to thank Mariana Souza, Nilton Almeida, Christian Vichi, Marco Tagliabue and two anonymous reviewers for comments on previous versions of the text. We have no conflicts of interest to disclose.

Correspondence concerning this article should be addressed to Angelo A. S. Sampaio, Colegiado de Pós-Graduação em Psicologia, Universidade Federal do Vale do São Francisco (Univasf), Av. José de Sá Maniçoba, s/n, Centro, Petrolina, PE, 56304205, Brazil. Email: angelo.sampaio@univasf.edu.br 
This manuscript is being published on an expedited basis, as part of a series of emergency

publications designed to help practitioners of applied behavior analysis take immediate action to address police brutality and systemic racism. The journal would like to especially thank Worner Leland and Melody Sylvain for their insightful and expeditious reviews of this manuscript. The views and strategies suggested by the articles in this series do not represent the positions of the Association for Behavior Analysis, International or Springer Nature.

Guest Editor, Denisha Gingles 


\begin{abstract}
A police stop must be based on founded suspicion, an officer's ability to correctly discriminate suspicious behavior. However, police stops can be influenced by negative attitudes towards Black individuals. We conducted a systematic review of empirical articles published from 2014 until 2019 that investigated the relationship between racial prejudice and police stops on PsycInfo, using keywords such as "race", "ethnic", "police stop", "traffic stop", and "stop and frisk". Results included 16 studies conducted in the United States (US), England, Wales, and the Netherlands, and showed that: Black men were the most frequent targets of police stops; many individuals who have been stopped by the police reported negative perceptions of the police force; the Stop, Question, and Frisk strategy used by some US police departments proved to be a type of stop that favors racial selectivity; and that traffic stops were favorable environments for racially biased actions by officers. We conclude that institutional racism in police stops proves to be a problem shared by several countries, including Brazil. We suggest more investigations to characterize institutional racism in the police force and in other settings and interventions aimed at reducing individual biases and collective racist practices.
\end{abstract}

Keywords: police stop, Terry stop, Stop and Frisk, systemic racism, racial prejudice, racial issues 


\section{Racial Prejudice and Police Stops: A Systematic Review of Empirical Studies}

In recent years, murders of Black ${ }^{1}$ men by White police officers have sparked outrage around the world. In Brazil, in 2013, Amarildo Dias de Souza, a Black man who worked as a bricklayer helper and who lived in Rio de Janeiro's Rocinha slum, disappeared after a police operation. Twenty-five officers were sued for Amarildo's disappearance, generating eight convictions, but the case is still under investigation. In 2014, a White officer murdered the 18-year-old Black American Michael Brown. Investigations showed that the young man was unarmed. The event sparked protests across the country (Chaney, 2015). These are just two examples of the many cases where police officers abused their power during operations (Barret et al., 2014; Cerqueira \& Moura, 2013; Sinhoretto, Batitucci, et al. 2014).

The police, an armed corporation responsible for maintaining and restoring order, is the primary public security service with which the community interacts. To pursue its mission, it carries out ostensible activities such as conducting stops, which can be defined as the "technique of stopping an individual or a group of people . . . with signs of suspicion; who have practiced or are on the verge of committing criminal offenses, to investigate, guide, warn, arrest, assist, etc.” (Boni, 2006, p. 29). Police stops should limit individual freedom according to the collective interest and be based on founded suspicion - a concrete and sure presumption of the level of suspicion of the individuals stopped (Boni, 2006). Although most police forces have operational manuals to guide its procedures, the way an officer conducts a police stop and/or search depends on their personal evaluation, which may be influenced by negative attitudes, for example about the suspect's race.

\footnotetext{
${ }^{1}$ The term "Black" (negro in Portuguese) is used here to denote individuals with African ancestry. In Brazil, the term is used both by government agencies and by individuals themselves.
} 
An attitude can be seen as a favorable or unfavorable evaluation of a stimulus or set of stimuli (e.g., Eagly \& Chaiken, 1993). Attitudes regarding racial issues have been discussed with related concepts such as: (1) racism, which can be seen as an ideology based on the belief that biological, phenotypic, and/or cultural differences are inherently related to moral, intellectual, and aesthetic characteristics of individuals (Munanga, 2004); (2) racial prejudice, a set of negative attitudes regarding an individual or group of individuals, based on this individual/group characteristics, such as skin color, type of hair and size of lips (Nogueira, 2006); and (3) institutional racism, a systemic form of prejudice which can be defined as "the failure of institutions and organizations to provide a professional and adequate service to people due to their color, culture, racial or ethnic origin" (Brasil, 2006, p. 22).

The influence of police officers' racial prejudices and the police institutional racism on Black individuals have been found, for instance, in Brazilian studies that: interviewed police officers and individuals who were stopped (Ramos \& Musumeci, 2004; Souza \& Reis, 2014), directly observed police stops (Ramos \& Musumeci, 2004; Silva, 2009; Sinhoretto, Batitucci, et al., 2014), analyzed police lethality data (Cerqueira \& Moura, 2013; Sinhoretto, Silvestre, et al., 2014), and examined statistical data resulting from the formalization of complaints (Duarte et al., 2014). This is a fundamental social issue, as the alarming number of young Black men killed in police encounters demonstrates. As one example, Sinhoretto, Silvestre, et al. (2014) analyzed 734 cases of deaths resulting from police conduct in the state of São Paulo, Brazil, between 2009 and 2011, and found that $61 \%$ were of Black individuals - while only approximately $30 \%$ of the population from São Paulo are Black.

This differential treatment for people of color can produce a distrusting relationship between the population and the police. For example, in a Brazilian survey 
on racial and ethnic characteristics of the population (Instituto Brasileiro de Geografia e Estatística, 2011), 68.3\% of the participants considered that justice and police were the fields with the greatest influence of racial biases, suggesting that Brazilians do not trust their own public security system. The consequences of this inefficiency have been discussed in the literature as institutional racism, which can be seen in the treatment given to Black users by institutions in different areas, such as education, health and security.

Of course, racially skewed police stops are not exclusive to Brazil. Since the 1990s, after episodes of police violence directed at young Blacks, the United States (US) has intensified the assessment of police practices in addressing the so-called street crimes. For instance, Gelman et al. (2007) analyzed 5,000 cases of Stop, Question, and Frisk (SQF) police approaches (also known as Terry Stops in some states), a US Street Police Department policy that allows police officers to search civilians in suspicious behaviors, looking for weapons or smuggled items. The results indicated that more Blacks and Hispanics were stopped, even when the study controlled for geographic variables, such as racial characteristics of the neighborhoods and criminal indexes of each district. Thus, Black and other underrepresented individuals are more prone to being stopped by the police. And during stops, they are more prone to suffer unnecessary use of force (Cerqueira \& Moura, 2013; Sinhoretto, Batitucci, et al., 2014). This produces immense behavioral consequences both to their relationship with the police itself and to other areas of their lives. For instance, the number of occurrences towards underrepresented groups could be higher due to the disproportional number of times they are stopped. In fact, Mizael and Sampaio (2019), in a behavioral and cultural analysis of the Brazilian police force, argued that the "war on drugs" (the policy of trying to reduce drugs trafficking at any cost) leads to higher policing of 
underprivileged areas, where there are more Blacks and people of color. Also, the unnecessary use of force towards underrepresented groups could lead to responses such as escape and avoidance in the form of freezing or hiding from the police, which could be seen by police officers as suspicious behavior, leading to more stops (and more fear and escape or avoidance responses by the individuals being stopped). Additionally, the unnecessary use of force could lead to a difference in attitude towards the police: while Whites could be more prone to see the police force as a positive and necessary group in the society, Blacks and other underrepresented groups could be more likely to relate the police force with negative attributes.

In this respect, any behavior analyst or social scientist working with this public or interested in them should be aware of the most recent evidence regarding the matter. The first step to planning any type of intervention is being aware of the current data. This facilitates the identification of gaps and the proposition of additional research and future application. More importantly, any professional interested in contributing to alter this fundamental social issue, should be familiar with empirical work that could inform organizational and cultural interventions (e.g., training and educational activities, culturo-behavior science and organizational behavior management applications) to pursue that end. In this direction, we carried out a systematic review of the literature to analyze recent results of empirical, archival and/or statistical research that investigated the relationship between racial prejudice and police stops.

\section{Method}

We searched PsycInfo, which covers themes of the behavioral and social sciences, with keywords related to racial issues and police stops: [race OR racial OR ethnic] AND [police stop OR traffic stop OR stop AND search OR stop AND frisk]. We also searched for the Portuguese translation of the keywords. Keywords must have 
appeared in the abstract. The search was filtered by type of document (journal articles only) and time period (2014 to 2019), and was carried out in October 2019. The inclusion criteria for the studies were: to be an empirical research (e.g., reviews and mathematical modeling studies were excluded) and to have primarily investigated the relationship between racial prejudice and police stops. The selected studies were analyzed regarding: (1) authors, (2) aims, (3) study design, (4) participants, (5) country, (6) dependent variables, (7) independent variables, and (8) main results found. The recommendations of the PRISMA group (Liberati et al., 2009) were considered for the presentation of the results.

\section{Results}

In the identification stage, no studies written in Portuguese and 23 studies written in English were found (with no repeated results). Of these, seven studies were eliminated: two for being non-empirical, and five for not being primarily related to racial prejudice and police stops. Thus, 16 studies were read in full and evaluated for eligibility, all of them being included. Table 1 summarizes the reviewed studies' main characteristics. The studies were carried out in the US, England, Wales, and the Netherlands; and mainly analyzed database or survey data.

\section{[Insert Table 1 about here]}

The studies main results on the relationship between racial prejudice and police stops showed, first, that a larger proportion of Black people (vs. other races), especially men, were stopped and exposed to excessive use of police force (Ariza, 2014; Motley \& Joe, 2018; Morrow et al., 2017; Svensson \& Saharso, 2015). Black men with lowincome were especially prone to that (Motley \& Joe, 2018). Furthermore, living in communities where the use of police force is common or racially skewed was associated with poor health (Sewell, 2017). 
As for the perceptions about interactions with the police, young Black participants reported having difficulty communicating with officers-especially for those that were not proficient at English, but also because some of them were afraid to ask questions, arguing that the police could see this type of behavior as defiance behavior, i.e., "being smart” (Barret et al., 2014). They also reported abuses of power and "over-policing" directed towards them, i.e., a more intense and frequent policing than necessary to maintain order (Barret et al., 2014). Additionally, research has found that Black participants reported more negative attitudes towards the police (Nadal et al., 2017). The only experiment included in our review further found that social contextual framing factors, such as the local climate of police-community relations, the legality of the stop, and the officer's work history have a similar or even higher effect than the race of participants on how citizens perceive and evaluate videos of actual police-citizen encounters (Braga et al., 2014).

During traffic stops, Black drivers were also stopped more often during the day than Whites, suggesting a racial bias, since it is harder to ascertain an individual's race during darkness (Ritter, 2017; Taniguchi et al., 2017). In addition, specific police units (e.g., the HEAT team) presented greater racial disparity in the number of stops conducted (Taniguchi et al., 2017). Blacks and Latinos received more traffic tickets than White drivers, and Black individuals were disproportionately targeted for discretionary searches (Gilliard-Matthews, 2017). Compared to White drivers, African-American drivers were more likely to experience an investigative stop, to experience more invasive inquiries in this kind of stop, and to receive a formal complaint (Epp et al., 2017).

The study by Vito et al. (2017) found that traffic stops with Black drivers were less likely to generate citations compared to that of other races, but the researchers 
suggested that this could be explained because officers believed Blacks were involved in more serious crimes. According to Voigt et al. (2017), police officer's utterances spoken to White community members during vehicle stops were consistently more respectful, but not more formal, than those directed at Black individuals, even after controlling for contextual factors such as the severity of the offense or the outcome of the stop. Related to that, a deteriorated setting was associated with a driver's race being described as African-American (Barnum \& Miller, 2014).

One study even found that officers' categorization of Black women's body weight in police stops' reports were racially biased, with Black women being more likely than White women to be labeled heavy and to be stopped in private rather than public spaces, even after controlling for diverse variables (Kwate \& Threadcraft, 2015).

\section{Discussion}

Institutional racism can be measured by the low level of access, quality or satisfaction with products and services (e.g., education, health) provided for specific racial/ethnic group(s) by an institution. This form of racial prejudice is a fundamental element in the maintenance of racial inequality in a society. As stated in the Brazilian Handbook to Fighting Institutional Racism, "what institutional racism produces is not only the lack of access and the low quality of access to services and rights, but it is also the perpetuation of a structural condition of inequality in our society" (Brasil, 2006, p. 13).

Taking those measures of institutional racism into account, the studies we reviewed clearly demonstrate the institutional racism present in police stops - at least in the countries where the research was conducted. Black people are systematically harmed by police actions, as evidenced in the studies reviewed. Having a biased police force interferes with the population's trust in the alleged aims of the police, that is, 
safety and order, especially by people of color and other underrepresented individuals. That produces a negative perception of police officers, reported by participants from studies carried out in three countries: the US (Braga et al., 2014), England (Barret et al., 2014), and in the Netherlands (Svensson \& Saharso, 2015).

The century-old idea that Black and other non-White individuals are inferior influences the behavior of members of a society, being reinforced in and by several institutions (e.g., religious, educational). Being present and reinforced in several contexts, this incorrect and outrageous idea becomes naturalized, that is, people tend to see it as a normal or natural feature of the environment and to avoid any form of countercontrol (see Sidman, 1989). However, a system that maintains institutional racism directly interferes with the quality of life of those targeted by racial selectivity during the stops and can generate popular protests and riots. In Nadal et al. (2017), for example, a 19-year-old Black American man reported: "I felt as if I did something wrong, despite me knowing that I didn't do anything. I felt bad about myself”' (p. 820). In addition to eliciting emotional responses often referred to as fear and nervousness in the presence of police officers, helplessness is also a common outcome, as expressed by an 18-year-old Latino man also from the Nadal et al. study: "It happens a lot, so it really doesn't matter" (p. 821).

The SQF approach was mentioned by two studies (Motley \& Joe, 2018; Sewell, 2017) from different countries (the US and England). These studies used police departments' data on stops to assess whether this practice disproportionally targets Blacks. Common results showed a racial discrepancy in the frequency of stops. As officers register the citizen's race according to their own pre-judgments, however, it is important to note that Barnum and Miller (2014) results suggest such data can be 
influenced by factors such as the stop site being a lower-income neighborhood, where officers tend to report the person as Black.

We found no research reported in Portuguese or conducted with Brazilians or other Portuguese-speaking citizens. This may be due to the keywords being searched in only one database. Thus, the selection of a single database is a limitation of our review. Despite that, data regarding institutional racism in the Brazilian police can also be found. According to Cerqueira et al. (2017), the number of registered deaths occurring in police interventions in Brazil during 2015 was extremely high $(3,320)$, even higher than the number of deaths after a robbery $(2,314)$. Critically, during the same year, $71 \%$ of murdered people in the country were Black. There are no data regarding the percentage of Black people killed during police interventions, but one can expect numbers at least equal to that for total murders. The negative perception of police officers by Black people is also present in Brazil. For example, a survey showed that $68.3 \%$ of Brazilian respondents believed that the police acted in a racially biased manner (Instituto Brasileiro de Geografia e Estatística, 2011).

Future research should investigate traffic stops—which proved to be a favorable environment for racial discrepancies in police procedures in the US (Barnum \& Miller, 2014) — in different countries, assessing the generality of this unfortunate phenomenon and its cultural particularities. Due to social and racial inequalities in Brazil, for instance, White people tend to have more financial resources, which influences the purchase of goods such as vehicles. In addition, cars are especially expensive in Brazil. Since we could not find studies relating racial prejudice and traffic stops in Brazil, researchers could investigate, for example, whether it is more common for police officers to stop Black people driving cars that are considered expensive, compared to White individuals and whether Black drivers are stopped more than Whites. 
The absence of studies in Brazil and other countries might also be due to the difficulty of accessing data on police stops. These data may not have been produced or made publicly available. Therefore, movements that demand constant production and publicity of data are paramount for researchers being able to collect data that could help delineate public policies.

Behavior analysts have contributed to studies on racial prejudice and institutional racism (de Carvalho \& de Rose, 2014; Mizael \& de Rose, 2017; Mizael et al., 2016; Mizael \& Sampaio, 2019). In that line, future research could investigate, for instance, the cumulative effect of prejudice in organizations such as the police force and some of the individual and cultural consequences that permits the maintenance of these behaviors, thus describing the components of the macrocontingencies involved (cf.

Glenn et al., 2016; Mizael \& Sampaio, 2019). These can help design cultural interventions aimed at reducing this and other types of prejudices - one thing that was unfortunately lacking in literature we reviewed. Interventions to fight racial prejudice and institutional racism are badly needed, and a behavior-analytic perspective might just be what is missing for us to win this battle.

A possible way that behavior analysts could ameliorate racial bias in police stops could be by analyzing strategies already used, such as training programs. Generally, those types of programs focus on presenting the audience (police officers) written and visual material describing how to better interact with civilians. According to Machado and Lugo (in press), this type of strategy could be effective to change verbal behavior. However, to establish specific skills (e.g., to use force only when no other alternative is possible), it could be more effective to use performance and competency-based strategies. In this sense, behavior analysts could evaluate the use of video modeling or behavior skills training to decrease racial bias in police stops. 
Body-worn cameras (BWCs) — cameras attached to a police officer chest area or head that record their interactions with civilians — are another strategy already in use (see Voigt et al., 2017). According to Machado and Lugo (in press), they are used by the US Department of Justice since 2005, and, each year, more cameras are available to police officers. According to the authors, BWCs could be seen as an antecedent manipulation that could evoke socially congruent behavior (covert rules or overt behavior), and/or increase the probability of behavior that could avoid the punitive consequences related to racial misconduct (Machado \& Lugo, in press). Those videos could also be used in sessions where a trainer reinforces professional behavior (e.g., by adding points that could lead to a higher salary) and where unprofessional behavior, such as the abusive use of force is accountable (e.g., the police officer loses points that decrease their salaries).

Racial bias in police stops is an urgent and fundamental matter affecting different aspects of society (e.g., health, traffic, imprisonment). Our review confirms the unfortunate and systematic presence of this social issue in different countries. We hope that such information can be useful in furthering more basic and applied research, helping to formulate interventions to reduce individual biases and to implement measures to decrease institutional racism. 


\section{References}

Studies included in the systematic review are identified with an asterisk (*)

*Ariza, J. J. M. (2014). Police-initiated contacts: Young people, ethnicity, and the “usual suspects”. Policing \& Society, 24(2), 208-223.

https://doi.org/10.1080/10439463.2013.784301

*Barnum, C., \& Miller, T. (2014). Neighborhood deterioration and perceptions of race. Current Research in Social Psychology, 22(10), 51-59. https://crisp.org.uiowa.edu/sites/crisp.org.uiowa.edu/files/2020$\underline{04 / \operatorname{art} 9.21 .14 \_0 . p d f}$

*Barrett, G. A., Fletcher, S. M. G., \& Patel, T. G. (2014). Black minority ethnic communities and levels of satisfaction with policing: Findings from a study in the north of England. Criminology \& Criminal Justice, 14(2), 196-215. https://doi.org/10.1177/1748895813483760

Boni, M. L. (2006). Cidadania e poder de polícia na abordagem policial. [Citizenship and police power in the police stop]. Revista da Faculdade de Direito de Campos, 7(9), 621-664. https://core.ac.uk/download/pdf/16012941.pdf

*Braga, A. A., Winship, C., Tyler, T. R., Fagan, J., \& Meares, T. L. (2014). The salience of social contextual factors in appraisals of police interactions with citizens: A randomized factorial experiment. Journal of Quantitative Criminology, 30(4), 599-627. https://doi.org/10.1007/s10940-014-9216-7

Brasil (2006). Guia de enfrentamento ao racismo institucional [Handbook on fighting institutional racism]. Gueledés - Instituto da mulher negra. http://www.onumulheres.org.br/wp-content/uploads/2013/12/Guia-de$\underline{\text { enfrentamento-ao-racismo-institucional.pdf }}$ 
Cerqueira D., Lima, R. S., Bueno, S., Valencia, L. I., Hanashiro, O., Machado, P. H. G., \& Lima, A. S. (2017). Atlas da Violência 2017. [Violence Atlas 2017]. Instituto de Pesquisa Econômica Aplicada; Fórum Brasileiro de Segurança Pública. https://www.ipea.gov.br/portal/images/170609_atlas_da_violencia_2017.pdf

Cerqueira, D. C. R., \& Moura, R. L. (2013). Vidas perdidas e racismo no Brasil [Lost lives and racism in Brazil] (Nota Técnica 10). Instituto de Pesquisa Econômica Aplicada (IPEA).

http://repositorio.ipea.gov.br/bitstream/11058/5977/1/NT_n10_vidas.pdf

Chaney, C. (2015). Institutional Racism: Perspectives on the Department of Justice's investigation of the Ferguson Police Department. Western Journal of Black Studies, 39(4), 312-330.

https://pdfs.semanticscholar.org/f0f3/00fa7ad4cc249d9189869fcf8535b6f55eda.p $\underline{\mathrm{df}}$

de Carvalho, M. P., \& de Rose, J. C. (2014). Understanding racial attitudes through the stimulus equivalence paradigm. The Psychological Record, 64(3), 527-536. https://doi.org/10.1007/s40732-014-0049-4

Duarte, E. C. P., Muraro, M., Lacerda, M., \& Garcia, R. D. (2014). Quem é o suspeito do crime de tráfico de droga? Anotações sobre a dinâmica dos preconceitos raciais e sociais na definição das condutas de usuário e traficantes pelos Policiais Militares nas Cidades de Brasília, Curitiba e Salvador [Who is the suspect in the drug trafficking crime? Notes on the dynamics of racial and social prejudices in the definition of user and trafficker's conduct by militar police officers in the cities of Brasília, Curitiba and Salvador]. In I. S. Figueiredo, G. C. Baptista, \& C. S. L. Lima (Eds.), Segurança pública e direitos humanos: Temas transversais (pp.81-120). Ministério da Justiça, Secretaria Nacional de Segurança Pública 
(SENASP). https://www.justica.gov.br/central-deconteudo/senasp/anexos/pensando-a-seguranca-publica_vol-5.pdf

Eagly, A. H., \& Chaiken, S. (1993). The nature of attitudes. In A. H. Eagly, \& S. Chaiken, (Eds.), The Psychology of attitudes (pp. 1-21). Fort Worth.

*Epp, C. R., Maynard- Moody, S., \& Haider- Markel, D. (2017). Beyond profiling: The institutional sources of racial disparities in policing. Public Administration Review, 77(2), 168-178. https://doi.org/10.1111/puar.12702

Gelman, A., Fagan, J., \& Kiss, A. (2007). An analysis of the New York City Police Department's "Stop-and-Frisk" policy in the context of claims of racial bias. Journal of the American Statistical Association, 102(479), 813-823. https://doi.org/10.1198/016214506000001040

*Gilliard-Matthews, S. (2017). Intersectional race effects on citizen-reported traffic ticket decisions by police in 1999 and 2008. Race and Justice, 7(4), 299-324. https://doi.org/10.1177/2153368716648002

Glenn, S. S., Malott, M. E., Andery, M. A. P. A., Benvenuti, M., Houmanfar, R. A., Sandaker, I., Todorov, J. C., Tourinho, E. Z., \& Vasconcelos, L. A. (2016). Toward consistent terminology in a behaviorist approach to cultural analysis. Behavior and Social Issues, 25, 11-27. https://dx.doi.org/10.5210/bsi.v.25i0.6634 Instituto Brasileiro de Geografia e Estatística. (2011). Características étnico-raciais da população [Ethnic-racial characteristics of the population]. Instituto Brasileiro de Geografia e Estatística. https://biblioteca.ibge.gov.br/visualizacao/livros/liv49891.pdf

*Kwate, N. O. A., \& Threadcraft, S. (2015). Perceiving the Black female body: Race and gender in police constructions of body weight. Race and Social Problems, 7(3), 213-226. https://doi.org/10.1007/s12552-015-9152-7 
Liberati, A., Altman, D. G., Tetzlaff, J., Mulrow, C., Gøtzsche, P., Ioannidis, J. P. A., Clarke, M., Devereaux, P. J., Kleynen, J., \& Moher, D. (2009). The PRISMA statement for reporting systematic reviews and meta-analyses of studies that evaluate health care interventions: Explanation and elaboration. PLOS Medicine, 6(7), e1000100. https://doi.org/10.1371/journal.pmed.1000100

Machado, M. A., \& Lugo, A. M. (in press). A behavioral analysis of two strategies to eliminate racial bias in police use-of-force. Behavior Analysis in Practice.

Mizael, T. M., \& de Rose, J. C. (2017). Análise do comportamento e preconceito racial: Possibilidades de interpretação e desafios [Behavior analysis and racial prejudice: Possibilities of interpretation and challenges]. Acta Comportamentalia, 25(3), 365-377. http://www.revistas.unam.mx/index.php/acom/article/download/61632/54291

Mizael, T. M., dos Santos, S. L., \& de Rose, J. C. (2016). Contribuições do paradigma de equivalência de estímulos para o estudo das atitudes. [Contributions of the equivalence class paradigm to studying attitudes]. Interação em Psicologia, 20(2), 124-134. http://dx.doi.org/10.5380/psi.v20i2.46278

Mizael, T. M., \& Sampaio, A. A. S. (2019). Racismo Institucional: Aspectos comportamentais e culturais da abordagem policial. [Institutional racism: Behavioral and cultural aspects of the police approach]. Acta Comportamentalia, $27(2), 215-231$. http://www.revistas.unam.mx/index.php/acom/article/download/69861/61628

*Motley, R. O., Jr., \& Joe, S. (2018). Police use of force by ethnicity, sex, and socioeconomic class. Journal of the Society for Social Work and Research, 9(1), 49-67. https://doi.org/10.1086/696355 
*Morrow, W., White, M., \& Fradella, H. (2017). After the stop: Exploring the racial/ethnic disparities in police use of force during Terry stops. Police Quarterly, 20(4), 367-396. https://doi.org/10.1177/1098611117708791

Munanga, K. (2004). Uma abordagem conceitual das noções de raça, racismo, identidade e etnia [A conceptual approach to the notions of race, racism, identity and ethnicity]. In A. A. P. Brandão (Ed.), Programa de educação sobre o negro na sociedade brasileira (pp. 16-34). EdUFF.

*Nadal, K. L., Davidoff, K. C., Allicock, N., Serpe, C. R., \& Erazo, T. (2017). Perceptions of police, racial profiling, and psychological outcomes: A mixed methodological study. Journal of Social Issues, 73(4), 808-830. https://doi.org/10.1111/josi.12249

Nogueira, O. (2006). Preconceito racial de marca e preconceito racial de origem: Sugestão de um quadro de referência para a interpretação do material sobre relações raciais no Brasil [Mark and origin: A framework for the analysis of racial prejudice in Brazil]. Tempo Social: Revista de Sociologia da USP, 19(1), 287308. https://doi.org/10.1590/S0103-20702007000100015

Ramos, S., \& Musumeci, L. (2004). Elemento suspeito: Abordagem policial e discriminação na cidade do Rio de Janeiro [Suspected element: Police stops and discrimination in the city of Rio de Janeiro]. Boletim Segurança e Cidadania, 3(8), 1-16. https://cesecseguranca.com.br/wpcontent/uploads/2016/03/boletim08.pdf

*Ritter, J. A. (2017). How do police use race in traffic stops and searches? Tests based on observability of race. Journal of Economic Behavior \& Organization, 135, 8298. https://doi.org/10.1016/j.jebo.2017.02.005 
*Sewell, A. A. (2017). The illness associations of police violence: Differential relationships by ethnoracial composition. Sociological Forum, 32(Suppl 1), 975997. https://doi.org/10.1111/socf.12361

Sidman, M. (1989). Coercion and its fallout. Authors Cooperative.

Silva, G. G. (2009). A lógica da polícia militar do Distrito Federal na construção do suspeito [The logic of the military police force from Distrito Federal in the construction of the suspected individual]. Sociedade e Estado, 24(3), 908-909. http://dx.doi.org/10.1590/S0102-69922009000300021

Sinhoretto, J., Batitucci, E., Mota, F. R., Schlittler, M. C., Silvestre, G., Morais, D. S., Souza, L. G., Sousa, R. R., Silva, S. S., Ovalle, L. A., Ramos, P. C., Almeida, F. B., \& Maciel, W. C. (2014). A filtragem racial na seleção policial de suspeitos: Segurança pública e relações raciais [Racial profiling in police selection of suspects: Public safety and race relations]. In C. S. L. Lima, G. C. Baptista, \& I. S. Figueiredo (Eds.), Segurança pública e direitos humanos: Temas transversais (pp. 121-159). Ministério da Justiça, Secretaria Nacional de Segurança Pública (SENASP). https://www.justica.gov.br/central-deconteudo/senasp/anexos/pensando-a-seguranca-publica_vol-5.pdf

Sinhoretto, J., Silvestre, G., \& Schlittler, M. C. (2014). Desigualdade racial e segurança pública em São Paulo: Letalidade policial e prisões em flagrante [Racial inequality and Public Safety in São Paulo: Police lethality and flagrant arrests]. http://www.ufscar.br/gevac/wp-content/uploads/Sum\%C3\%A1rioExecutivo_FINAL_01.04.2014.pdf

Souza, J. L. C. D. \& Reis, J. F. G. (2014). A discricionariedade policial e os estereótipos suspeitos [Police discretion and suspect stereotypes]. Revista do NUFEN, 6(1), 125-166. http://pepsic.bvsalud.org/pdf/rnufen/v6n1/a07.pdf 
*Svensson, J. S., \& Saharso, S. (2015). Proactive policing and equal treatment of ethnic-minority youths. Policing \& Society, 25(4), 393-408. https://doi.org/10.1080/10439463.2013.875015

*Taniguchi, T. A., Hendrix, J. A., Levin-Rector, A., Aagaard, B. P., Strom, K. J., \& Zimmer, S. A. (2017). Extending the veil of darkness approach: An examination of racial disproportionality in traffic stops in Durham, NC. Police Quarterly, 20(4), 420-448. https://doi.org/10.1177/1098611117721665

*Vito, A. G., Grossi, E. L., \& Higgins, G. E. (2017). The issue of racial profiling in traffic stop citations. Journal of Contemporary Criminal Justice, 33(4), 431-450. https://doi.org/10.1177/1043986217724537

*Voigt, R., Camp, N. P., Prabhakaran, V., Hamilton, W. L., Hetey, R. C., Griffiths, C. M., Jurgens, D., Jurafsky, D., \& Eberhardt, J. L. (2017). Language from police body camera footage shows racial disparities in officer respect. Proceedings of the National Academy of Sciences, 114(25), 6521-6526.

https://doi.org/10.1073/pnas.1702413114 


\section{Table 1}

Summary of the Studies Reviewed

\begin{tabular}{|c|c|c|c|c|c|c|c|}
\hline Authors & Aims & Study Design & Participants & Country & $\begin{array}{l}\text { Dependent } \\
\text { Variables }\end{array}$ & $\begin{array}{l}\text { Independent } \\
\text { Variables }\end{array}$ & Main Results \\
\hline $\begin{array}{l}\text { Ariza } \\
(2014)\end{array}$ & $\begin{array}{l}\text { Factors that affect } \\
\text { the likelihood of } \\
\text { police contacts with } \\
\text { individuals }\end{array}$ & $\begin{array}{l}\text { Statistical } \\
\text { Analysis of } \\
\text { Survey Data }\end{array}$ & $\begin{array}{l}4,600 \text { people } \\
\text { aged between } 10 \\
\text { and } 25, \text { who had } \\
\text { experienced } \\
\text { contact with the } \\
\text { police in } 2005\end{array}$ & $\begin{array}{l}\text { England and } \\
\text { Wales }\end{array}$ & $\begin{array}{l}\text { Probability of } \\
\text { contacts initiated } \\
\text { by the police; } \\
\text { type of contact } \\
\text { with the police }\end{array}$ & $\begin{array}{l}\text { Sex, type of housing } \\
\text { (owned/rented), } \\
\text { family income, age, } \\
\text { and race }\end{array}$ & $\begin{array}{l}\text { Having friends in conflict with the law, } \\
\text { being male, being aged } 14 \text { to } 17 \text {, and } \\
\text { being part of a racial minority } \\
\text { (especially being Black) increased the } \\
\text { likelihood of police initiating contacts. }\end{array}$ \\
\hline $\begin{array}{l}\text { Barnum \& } \\
\text { Miller } \\
(2014)\end{array}$ & $\begin{array}{l}\text { Relations between } \\
\text { characteristics of a } \\
\text { neighborhood and } \\
\text { perceptions of race } \\
\text { in ambiguous } \\
\text { conditions, such as } \\
\text { poor lighting }\end{array}$ & $\begin{array}{l}\text { Statistical } \\
\text { Analysis of } \\
\text { Database and } \\
\text { Survey Data }\end{array}$ & $\begin{array}{l}\text { Drivers stopped } \\
\text { by the Davenport } \\
\text { PD between late } \\
2010 \text { and early } \\
2011\end{array}$ & US & $\begin{array}{l}\text { Observers' } \\
\text { perception of the } \\
\text { driver's race }\end{array}$ & $\begin{array}{l}\text { Social characteristics } \\
\text { of a neighborhood } \\
\text { (e.g., abandoned } \\
\text { houses, poor } \\
\text { lighting); time of day } \\
\text { during the stop } \\
\text { (night/day) }\end{array}$ & $\begin{array}{l}\text { Poor lighting and abandoned houses } \\
\text { were significantly related to the } \\
\text { likelihood of observers indicating the } \\
\text { driver's race as African-American. }\end{array}$ \\
\hline $\begin{array}{l}\text { Barret et al. } \\
\quad(2014)\end{array}$ & $\begin{array}{l}\text { Level of satisfaction } \\
\text { of minority } \\
\text { communities with } \\
\text { the police service }\end{array}$ & $\begin{array}{l}\text { Mixed- } \\
\text { methods } \\
\text { approach }\end{array}$ & $\begin{array}{l}45 \text { ethnic } \\
\text { minorities } \\
\text { participants living } \\
\text { in Northern } \\
\text { England }\end{array}$ & England & $\begin{array}{l}\text { Level of } \\
\text { satisfaction with } \\
\text { the police force }\end{array}$ & $\begin{array}{l}\text { Being a victim of a } \\
\text { crime; how } \\
\text { communities were } \\
\text { supervised by the } \\
\text { police }\end{array}$ & $\begin{array}{l}\text { Communication with the police was } \\
\text { described as being hampered by } \\
\text { language difficulties and fear of asking } \\
\text { questions. Young people, especially } \\
\text { Blacks, reported "over-policing" and } \\
\text { abuses of power during police stops. }\end{array}$ \\
\hline $\begin{array}{l}\text { Braga et al. } \\
\qquad(2014)\end{array}$ & $\begin{array}{l}\text { Effects of social } \\
\text { contextual variables } \\
\text { on the evaluation of } \\
\text { officers' behavior } \\
\text { during stops }\end{array}$ & Experimental & $\begin{array}{l}1,361 \text { participants } \\
\text { aged } 18+\text {, living in } \\
15 \text { US cities }\end{array}$ & US & $\begin{array}{l}\text { The perception of } \\
\text { police procedures } \\
\text { in traffic and } \\
\text { street stops }\end{array}$ & $\begin{array}{l}3 \text { videos of } \\
\text { appropriate and } \\
\text { inappropriate police } \\
\text { use of force; race, } \\
\text { sex, age, and income } \\
\text { of participants; } \\
\text { previous history with } \\
\text { the police and } \\
\text { political ideology }\end{array}$ & $\begin{array}{l}\text { Negative professional history of the } \\
\text { police officer, police-community climate } \\
\text { in the city, citizen characteristics, and } \\
\text { legal circumstances engendered } \\
\text { negative evaluations of police officer's } \\
\text { behavior }\end{array}$ \\
\hline $\begin{array}{l}\text { Kwate \& } \\
\text { Threadcraft } \\
(2015)\end{array}$ & $\begin{array}{l}\text { Factors associated } \\
\text { with officers' } \\
\text { categorization of } \\
\text { Black women's body } \\
\text { weight }\end{array}$ & $\begin{array}{l}\text { Statistical } \\
\text { Analysis of } \\
\text { Survey Data }\end{array}$ & $\begin{array}{l}\text { All NYPD police } \\
\text { stops from } 2003 \\
\text { to } 2012\end{array}$ & US & $\begin{array}{l}\text { Police officer's } \\
\text { categorization of } \\
\text { body weight }\end{array}$ & $\begin{array}{l}\text { Suspect's race, age, } \\
\text { height, and weight; } \\
\text { frisked or not; Black } \\
\text { precinct or not; date } \\
\text { of the stop; inside or } \\
\text { outside stop }\end{array}$ & $\begin{array}{l}\text { Black women were more likely than } \\
\text { White women to be labeled heavy and } \\
\text { to be stopped inside rather than } \\
\text { outside, even after controlling for all } \\
\text { other variables. }\end{array}$ \\
\hline
\end{tabular}


Relationship Saharso policing and unequal (2015) treatment of young

ethnic minorities

Racial disparities in the number of

occurrences,

Epp et al.

reasons, and

formalization of

complaints in police

stops

To compare, in 1999 and 2008 , under

Gilliard

$\begin{array}{ll}\text { Mathews } & \text { which conditions } \\ \text { (2017) } & \text { drivers received }\end{array}$

most traffic tickets

Circumstances

prevalence, and

Morrow et

al. (2017)

redictors of the use

of force in Terry stops

To describe

perceptions of law enforcement in the

Nadal et al community, and how (2017) unjustifiable

interactions with the

police affect

participants

responses

Ritter Whether driver's

(2017) race and time of day
231 people aged

Survey between 12 and

25 years old

Survey

45 Kansas PD

officers and 2,329

drivers stopped

Residents over 16 years old with one or more

Statistical

Analysis of Survey Data

encounters with the police in the past 12 months

Statistical

Analysis of Survey Data

Police officers from the NYPD

503 college

students and/or

Mixed-

methods

approach

fraternities: 124

Whites, 97 Blacks,

291 Latinos/

\section{Asians}

Statistical

Analysis of

Database Data

Officers of and people stopped by
US Racial disparities
Young people's perceptions of

preventive

police

in police stops

"Dutch" physical appearance, sex, delinquency, and association with delinquent groups

Frequency, reason given for stopping, citation, violations,

driver's race, type of clothing they

commonly wear, age sex, vehicle's make, model, year, location

$$
\text { of the stop }
$$

Legal reasons for stopping, geographic dimensions of the

place, sex, age and number of occupants of the vehicle

Age, sex, income, race (Black/White),

$$
\text { situational }
$$

xcessive use of police force and perceptions of police actions

characteristics of the suspected individual, type of police unit in the region

Perceptions of law enforcement in their daily lives

Race, age, sex, intersections between race and gender

A police officer's decision to stop a

Race and period of the day
Young individuals with a non-Dutch stereotypical appearance reported a greater number of preventive contacts with the police, a greater frequency of the use of instruments such as sprays and batons against them, and lower quality in the interactions.

African Americans were 2.7 times more likely to experience an investigative stop.

Young people received traffic tickets more often. Blacks and Latinos received more traffic tickets than White drivers. $47 \%$ of drivers stopped were Black.

Non-weapon use of force occurred more frequently against Blacks and Hispanics, compared to Whites.

Negative views of the police were more common among Blacks, in comparison with Whites and Latinos.
The percentage of Blacks drivers being stopped was between $5 \%$ and $7 \%$ 
predicted an officer's decision to stop

Relationship between reported health and living in neighborhoods with frequent excessive use of police force

the Minneapolis

PD in 2002

36,188 US

Relationship

between lightening

Taniguchi

et al. (2017)

of Black/White

drivers stopped by

the police unit

Vito et a

Circumstances in

which police officers

generate citations

Level of respect in

the language police

Voigt et al.

(2017)

officers used in

stops with

and Black

individuals

Examine self-

reported exposure

Motley \&

Joe (2018) and perceptions of
Statistical

Analysis of

Database and

Survey Data residents and

2009-2012 New

York City SQF

Database
Statistical

Analysis of

Database Data
Drivers and police

officers living in

Durham

Louisville PD's officers and individuals stopped in 2002

Analysis of

Database Data

Analysis of police officers' body-worn

628 Black drivers, 299 White drivers,

$$
245 \text { officials of }
$$

footage

Oakland, CA

Statistical

Analysis of

US residents aged

16 or more: 59

Blacks, and 366 Whites
Health indices

(diabetes,

hypertension,

and obesity)

driver and

conduct a search

Degree of use of

force in police stops,

race of the person

stopped,

characteristics of the neighborhood where

the stop took place

Time of day (day, sunset, night), year (2010-2015), sex, law

Racia

in stops

enforcement unit

(Uniform patrol,

HEAT, Traffic

Services or

interdiction)

Driver's race and sex, police officer's

Citations as a result of a stop

motives relate stop (according to

focal concerns theory)

Statements mitted by police officers to Black and White drivers

in police stops

Excessive use of police force and perceptions of police actions

Level of respect, cordiality, formality, impartiality, etc. present in the

Age, sex, income race: Black/White disproportionality lower during darkness, compared to the percentage of White drivers

Living in minority communities with common use of police force against pedestrians was associated with an increased risk of presenting obesity and diabetes. Living in a White community where the use of police force is racially skewed was correlated with an increased risk of obesity, diabetes, hypertension, and poor or fair reported health

A significant relationship was found between daylight and race for Black male drivers. The HEAT Team was $62 \%$ more likely to stop a Black man during the day than at other times.

$34 \%$ of drivers stopped were Black, and $70 \%$ were men; $67 \%$ of the stops

generated citations. Black drivers were $42 \%$ less likely to issue a citation compared to other races (supposedly, because officers believed Blacks were involved in more serious crimes).

Statements given to White drivers were more respectful than those emitted towards Black drivers (even when controlling the context of the interaction)

The lower the income, the greater the excessive use of force for both race groups, in both sexes. Black men reported a higher frequency of excessive use of force, such as 
Note. The studies are ordered by year of publication. SQF = Stop, Question and Frisk. HEAT = Police team responsible for carrying out services such as proactive problem solving, and drug transfers at street level. PD = police department. NYPD = New York Police Department. Excessive use of police force $=$ Degree of force above the appropriate level to a given situation, ranging from giving a warning to the lethal use of force with a weapon. 